\begin{tabular}{lcr}
\hline \multicolumn{1}{c}{ A N N A L E S } \\
UNiversitatis & MARIAE CURIE-SKŁODOWSKA \\
LUBLIN - POLONIA & 2020 \\
\hline
\end{tabular}

University of Opole. Faculty of Political Sciences and Social Communication

MICHAŁ NIEBYLSKI

ORCID ID: 0000-0003-1623-5886

\title{
Methodological Aspects of Studying Ideological Changes in the Context of Political Parties
}

Metodologiczne aspekty badania zmian ideologicznych w kontekście partii politycznych

\begin{abstract}
The purpose of this article is to analyse the methodological aspects related to the study of ideological changes in political parties. The article compares the quantitative analysis of election programs and the Expert Survey, evaluates their strengths and weaknesses, and analyses their application possibilities. The hypothesis adopted in this article is as follows: quantitative analysis of election programs is burdened with smaller methodological weaknesses than Expert Survey and thus is a more reliable tool for measuring ideological changes in the environment of political parties.
\end{abstract}

Keywords: political parties, ideological changes, quantitative analysis of election programs, Expert Survey

\section{INTRODUCTION}

The need to meet the requirements of conducting effective rivalry for power forces political parties to introduce various types of changes (personal, strategic, program and ideological). Although each change is related to certain risk for the parties, most of them accepts it and expects that the implemented changes will benefit them in the form of, among others, expanding the electoral base or improving the electoral result. Despite the fact that the readiness to introduce changes is a feature of nearly all parties participating in the political rivalry, it is necessary to note that the scale and scope of the implemented changes depend on many various factors, starting with the party's position in the political scene, through the state of resources 
(human, intellectual resources) available in the changes' implementation process and ending with the objectives of a given political environment.

The purpose of this paper is to analyse the methodological aspects related to studying ideological changes in political parties. The paper features a distinction of two general methods of specifying the ideological identity of parties. The first manner, deemed as static, is based on assigning specific ideological families to a party. In the case of most parties, this assignment is done once in the party's entire lifecycle (although there are obviously exceptions from this rule). The use of this framework basically excludes the ability to track the phenomenon of ideological changes in parties. In terms of the second framework, parties are treated as dynamic constructs which are subject to continuous (smaller or greater) changes which then affect the revision of their ideological identity. The dynamic approach can include five research approaches which use various data sources and methods of acquiring empirical material to determine the parties' positions in the ideological axis.

This paper will feature an attempt to compare and evaluate the assumptions adopted as part of two research approaches - the election programs' quantitative analysis (according to the standard developed by the Research Manifesto Group) and the Expert Survey. This choice is justified by the fact that most attempts of measuring ideological changes in political parties utilises the methodological procedures or the first or second approach. The prevailing view among researchers is that they have the greatest application value among all research approaches. For this reason, it is worth taking a look at the main assumptions of these approaches and inspect the weaknesses of the measurement conducted with their use.

The analyses included in this paper will serve to provide answers to the following research questions: 1) What are the differences between the static and dynamic framework of political parties' ideological identity?, 2) How is the ideological changes phenomenon measured in the research approaches adopting the dynamic framework of ideological identity?, 3) What differences are there between the quantitative analysis of election programs and the Expert Survey?, 4) What are the weaknesses of both approaches?, 5) Which of the approaches is better in terms of measuring ideological changes in the political parties' environment?

The paper features a hypothesis that the quantitative analysis of election programs features lesser methodological weaknesses than the Expert Survey and thus constitutes a more reliable tool for measuring the ideological changes in the political parties' environment.

\section{STATIC FRAMEWORK OF PARTIES' IDEOLOGICAL IDENTITY}

The static method of determining the parties' ideological identity is to group parties into ideological families. Andrzej Antoszewski argues that the productivity of this solution is that most parties execute auto-identification by indicating the ide- 
ological trends to which it refers systematically or at least selectively [Antoszewski 2005: 42-43].

Viewing parties in terms of their affiliation to ideological families requires dealing with problems related to the construction of a key through which the parties can be assigned to proper ideological families. Michael Gallagher, Michael Laver and Peter Mair proposed three criteria which, in their opinion, allow for unequivocal resolution of the issue of the parties' ideological affiliation [Gallagher, Laver, Mair 2001: 202]. One of them is the genetic criterion, which refers to similarities constituting a derivative of analogous historical circumstances of their formation or their intent to represent similar interests. In Cas Mudde's opinion, the criterion conceptualised in this manner reflects the assumptions specific for the socio-political divisions concept of Stein Rokkan and Seymur M. Lipset [Mudde 2002: 3]. These assumptions were, however, criticised repeatedly and their partial obsolescence was demonstrated (of the freezing hypothesis, among others) ${ }^{1}$. Due to this fact, as stated by Mair and Mudde, "an approach that focuses solely on the party's origins as the key for their contemporary classification bears the risk of omitting more aspects than it can offer instead" [Mair, Mudde 1998: 216]. They are mainly speaking of exhibiting the party's formation stage at the cost of its growth, evolution and institutionalisation. This process can result in a radical transformation of the ideological identity when compared to the prototype. A different problem is being revealed in the Central and Eastern Europe countries, including Poland, where the formation and trajectory of political parties' growth was subject to completely different historical conditions than in the West European model.

The criterion based on the parties' organisational links with transnational party structures (e.g. the Socialist International) or party alliances, e.g. Euro-parties acting in the European Parliament's forum (European People's Party), was deemed as useful. However, the use of the aforementioned criterion in terms of the classification applications requires great care. This is demonstrated by the numerous drawbacks of this criterion, which are specified by Vít Hloušek and Lubomir Kopeček. The most important drawback is that until now not all ideological orientations possess representation in the form of international party platforms associating the most important parties for the given trend (e.g. there is a lack of a representative structure for a radical right-wing party) [Hloušek, Kopeček 2010: 9-11]. Moving onwards, it is necessary to point out the difficulty in explicit definition of the ideological profile of some organisations which, by opening to political forces with an incompletely analogous ideological and program traits, do not currently represent clear ideological contours. An example of this thesis is the European People's Party (EPL), which

1 Maria Maguire [1983: 67-94] analysed the social support for political parties in fifteen democratic countries between 1948 to 1979 to check the up-to-dateness of the freezing hypothesis. During the post-war years, she observed stabilisation of the West European party systems, but this state collapsed after 1960 . The period of 1960-1979 was dominated by a new trend characterised, on the one hand, by high fluctuation of electoral behaviours and serious reshuffling in the European political scenes, on the other. 
was first thought of as a Christian democratic initiative, whereas today it brings considerably more connotations (liberal, conservative, people-related) [Gagatek 2007: 99-125]. Its structures feature various options, such as: the Civic Platform (PO), Polish People's Party (PSL) or other EU state parties, such as the Swedish Moderate Coalition Party (Moderaterna), Austrian People's Party (OVP), and finally Viktor Orbán's Fidesz ${ }^{2}$. The organisational criterion can lead to erroneous conclusions also because participation in international political alliances does not necessarily have to be an authentic expression of ideological auto-identification, but can be a specific smokescreen hiding political calculations aimed at integrating with organisations that guarantee a greater impact on shaping political issues [Hloušek, Kopeček 2010: 11].

Formations' classification to particular ideological families can also be done based on the program criterion, which specifies the degree to which the policy of a given party in the given country corresponds to the policy conducted by parties from other countries. However, according to Mudde, the ability to compare the policies implemented at the national level are limited due to the non-uniformity of the general conditions (political, social, economic, cultural) in which they are created and implemented [Mudde 2002: 5]. The researchers' response to the drawback of the proposal made by Gallagher, Laver and Mair was the search for other determinants attesting to a party's ideological affiliations. Klaus von Beyme laid the foundation for a new classification approach and took into consideration the party's name, and if this criterion failed, he supplemented it by studying the public opinion's reception of its ideological identity [von Beyme 1985: 3]. Basing the classification activities on the formation's name is far from sufficient, because it does not provide the answer to the question of ideological family affiliation. Furthermore, the use of this criterion brings several substantial doubts. It is interesting whether a change in the party's brand actually settles upon the issue of a new ideology's establishment. The question of whether there can be substantial ideological differences between parties with similar names is equally interesting. Finally, must it be deemed that parties which avoid ideological references in their names are outside of any ideological family? Completeness is also not a trait of the criterion which, in the German political scientist's opinion, is to perform supporting functions. Its main weakness is that it shifts the centre of gravity from the political actor's level to the social level. On the one hand, it is correlated with the devaluation of intents, actions and intentions of party decision-makers, whereas on the other - appreciation of the aspect related to social reception of their ideological position. In these terms, there is the question of whether the ideological profile evaluation can be deemed as reliable if it is does not overlap with the party's auto-declarations or is based on false prerequisites which hinder the correct overview (e.g. negative campaign organised by the rival political camp).

2 On 20 March 2019, the political assembly of the European People's Party decided to suspend Fidesz's membership. 
Apart from the difficulties in classifying parties in ideological families, it is necessary to state that the static framework, to which the ideological family classification is related, possesses limited ability of describing the party's ideological identity. Despite the fact that during the party's genetic stage, i.e. at its formation, the ideological family classification is subject to a relatively low risk of error, then along with the party's ideological evolution and growth, the original classification corresponds to the actual ideological identity to a lesser and lesser degree. The static framework depreciates the significance of the ideological changes introduced during latter stages of the party's life. This features two basic assumptions. Firstly, that auto-creation activities performed by the party environment in the party formation process are decisive in relaying an ideological identity. Secondly, that the ideological identity specified at the beginning of the party's existence remains unchanged in the long term. Both assumptions must be approached critically. The first assumption demonstrates a reductionist inclination. The shaping of ideological identity cannot be treated as a single activity which is concluded in the party's genetic stage. It is rather procedural and takes place at each stage of the party's functioning in political life. On the other hand, the second assumption deserves criticism due to showing simplistic tendencies. Viewing ideological identity as a construct which is de facto resistant to changes excludes a broad series of activities initiated inside the party, aimed at revaluating the current assumptions and developing new identity formats (casus of the so-called Third Way in social-democratic parties, such as: the German Social-Democratic Party or the Labour Party in Great Britain) from research interests.

\section{DYNAMIC FRAMEWORK OF PARTIES' IDEOLOGICAL IDENTITY}

Taking into consideration the dynamic nature of cross-party rivalry on the one hand and the increasing ability of parties' to adapt to the changing social and political situation on the other, coerces the departure from the static framework of ideological identity and adopting the perspective assuming a labile nature of the parties' identities. This means that ideological identity is not definitely assigned to a party, because it is treated as in statu nascendi.

The source of information on the parties' ideological identity are the positions of parties in the ideological axis. The spatial models usually take on a one- or two-dimensional form. Anthony Downs' work gave rise to the trend of positioning parties in the axis based on the proposed political programs [Downs 1957a: 135-150]. According to his theory, the left-right wing dimension came down to the issue of the state's engagement in economic life. Currently, bringing the left-ring wing division down only to economic aspects would be regarded as a sign of reductionism. As a result, the division into left- and right-wing would be deemed as an inadequate tool for presenting the parties' ideological positions. Today, the left- and right-wing attitude identifiers consist of social, economic, axiological and political issues. This 
implies an increasing use of the two-dimension model. As noted by Wojciech Rafałowski, the application of this approach is also encouraged by the fact that social and economic as well as axiological issues can be treated as independent sets of beliefs (support for free market economy or state interventionism is not related to supporting permissivism or traditionalism) [Rafałowski 2014: 64-65]. Many contemporary classification proposals are based on the two-dimensional scale. In Alain Noël and Jean-Philippe Therién's model, the left-right wing continuum intersects with the vertical authority-freedom axis [Noël, Therién 2008: 25]. According to Krzysztof Zuba, the interventionism-free market dichotomy (equivalent of the left-right wing dyad) intersects with the division into the traditionalist and open world view [Zuba 2012: 206]. The use of a two-dimensional scale allows for a more precise description of the changes occurring in the political scene and, at the same time, presents the given parties' positions more clearly. In his attempts at positioning political entities in abstract ideological spaces (regardless of whether these are one- or two-dimensional spaces), Mair notes the tendencies to make generalisations followed by the comparative studies' imperative [Mair 2003: 11].

The political science studies' practice features five research approaches which assume the dynamic nature of a party's ideological identity and allow for tracking the ideological changes in the party's environment. The first approach is based on analysing the contents of party documentation (mainly election campaigns). The second approach utilises public opinion surveying. It is possible to distinguish two variants in this approach. In the first variant, the ideological auto-identifications of electoral groups are identified with the position of their political representation. In the second variant, the groups evaluate the position of particular political formations in the ideological universe. The third approach is based on analysing the budget expenses' structure. In this approach, it is deemed that the party's ideological position can be determined by analysing, one would say, the tangible effects of their actions, i.e. the manner in which it formed the budget. For example, the allocation of greater resources for social programs can indicate the given party's left-leaning tendencies. On the other hand, tax or public expenditure reduction, including aid for the weakest groups, can be a predictor of right-leaning identity. The fourth approach's specificity is expressed in seeking the source of a party's position in the ideological axis in experts' knowledge. The experts surveys are conducted to gather this knowledge. The last approach draws knowledge of parties' ideological changes based on analysing the roll call voting ${ }^{3}$.

As already mentioned, the comparative analysis conducted in this paper covered two approaches: the quantitative analysis of election programs (acc. to the CMP standard) and the Expert Survey.

3 More about the roll call voting [Carrubba et al. 2006: 691-704]. 


\section{QUANTITATIVE ANALYSIS OF ELECTION PROGRAMS}

The methodological procedures of studying the contents of political programs were developed by a team of researchers surrounding the Research Manifesto Group. The basis of the method developed by them features four central assumptions. Firstly, election programs are a source of information about the political parties' ideological evolution. As discussed by Hans-Dieter Klingemann, programs

[...] determine the significance of the current political problems by specifying the party's attitude towards them and inform the electorate about the course of action executed by the party after the election. With few exceptions, all election programs $[\ldots]$ are legitimised as the party conventions. Therefore, they represent the official point of view, which is obviously aimed not only to unite the party internally, but - using mass media - to attract voters and win the election [Klingemann 1987: 300].

Secondly, parties differentiate the weight of particular issues. Thirdly, in their election programs, they devote the most attention to issues which, in their opinion, are the most important [Markowski 2002: 82]. Due to the above, the key to winning the rivalry is the effective imposition of a monopoly in setting the leading topics of the electoral campaign. Fourth, the universal tool for describing the ideological stances represented by parties is the left-right wing dyad [Budge, Klingemann 2001: 19-21]. This means that the stances can be grouped according to the continuum logic - from far-left to far-right attitudes.

The traditional issues around which party election programs are focused were grouped into fifty-six categories assigned to seven issue areas (these include international relations, freedom and democracy, political system, economy, welfare and quality of life, fabric of society, social groups) [Werner, Lacewell, Volkens 2011: 7]. It is deemed that this matrix encompasses the entire spectrum of issues around which the political actors' interest is focused. The study's purpose is to determine the "space" devoted in party programs to a given issue (the units of analysis are the so-called quasi-sentences) ${ }^{4}$, whereas $100 \%$ is deemed as all sentences in the analysed document. The coding process is based on assigning a quasi-sentence only to a single category (each category is a variable, whereas the variable's values are percentages of quasi-sentences devoted to the given issue). Therefore, the more space in an election program is devoted to a given issue, the more important it is for a party [Bukowska, Cześnik 2002: 270].

The positioning of a party in a one-dimensional ideological space (i.e. the leftright wing axis) is done by using the RILE (Right-Left Index) [Budge 2013: 2-3]. Among fifty-six categories, twenty-six were qualified for the measurement by distin-

4 A quasi-sentence, as explained by Andrea Volkens [2001: 34], is defined as a verbalised expression of a specific idea or issue. 
guishing them evenly among left- and right-wing categories. The index is calculated by summing up the percentage share of right-wing categories and deducting the percentage share of left-wing categories from all categories. In short, the operation can be expressed by using the following formula: $(\mathrm{R}-\mathrm{L}) /(\mathrm{R}+\mathrm{L}+\mathrm{O})$, where $\mathrm{R}$ - are rightwing categories, $\mathrm{L}-$ left-wing categories and $\mathrm{O}$ - other categories [Jahn 2011: 747]. For example, if the given party's election program consists of two hundred statements, forty of which have right-wing references $(20 \%)$, while one hundred - leftwing affiliations $(50 \%)$, the equation gives the result of -30 . In theory, the scale's range starts at -100 and ends at +100 , where -100 means far-left positions, +100 - far-right positions and 0 - central positions ${ }^{5}$. This means that a party, let us name it "X", when preparing for election rivalry, positioned itself in moderate left-wing positions. Thanks to the methodological procedure's iteration for the next election, we will obtain data not only on the current position of party $\mathrm{X}$ in the left-right wing axis, but also about its ideological changes since the last election. Let us assume that the new election program of party $\mathrm{X}$ was expanded by two hundred statements referring to issues not directly related to left-wing or right-wing positions. In general, the program's structure now consists of four hundred statements, whereas the number of left-wing or right-wing views did not change. However, their percentage share in the general number of statements was reduced respectively to $25 \%$ and $10 \%$. If we substitute the data to the relevant formula, we obtain the result of -15 . It is therefore possible to state that party $\mathrm{X}$, when compared to the previous election (in which it obtained the result of -30), shifted towards the centre, which means a transition from the clear left-wing identity towards emphasising a more centre-left ideological nature.

Along with the dissemination of the CMP method in the studies on the political parties' ideological evolution, election manifests gained the rank of the main source of information about the political actors' behaviours. This solution quickly became the subject of criticism. In Ricardo Pelizzo's opinion, the CMP method, instead of identifying the parties' ideological positions in the left-right wing axis only determines the parties' intents to shift positions to adapt to the current political situation. For this reason, he deemed the method to be a failure as a localiser of the parties' ideological positions [Pelizzo 2003: 83]. However, the Italian researcher's objection is not fully legitimate, because in countries with stabilised democracies, the election manifest is treated as a type of contrast between political parties and their electoral groups. It is also necessary to note that in the Polish conditions, the significance of election programs was substantially appreciated after the electoral victory of Law and Justice (PiS) in 2015, when the party justified the execution of controversial social and political reforms by the fact that it was obliged by their election program. As shown by numerous empirical studies, the role of election programs does not, however, only come down to declarations, because they become a determinant of

5 In practice, the result achieved by political parties is most often in the range of -50 to +50 [Mikhaylow, Laver, Benoit 2012: 80]. 
the policy executed by parties after getting to know the electoral verdict [McDonald, Mendes, Budge 2004: 1-26]. The observed change in the parties' approach to specific issues, expressed at the level of election programs, has more consequences in terms of the political practice. For this reason, we cannot belittle the importance of election manifests or ignore the relations between the program declarations and latter activity in the political scene.

The discussion over the validity of the assumptions adopted in the CMP featured also other weaknesses. It was noted that adopting a rigid, arbitrary semantic scheme of the "left-wing" and "right-wing" categories in this approach ignores the fact that the dichotomy is a contextual creation in the sense that it does not have a single fixed set of meanings, but is crystallised in relation to the systemic, social and cultural context [Jahn 2011: 760]. Due to the above, there can be differences in understanding this division in particular countries. As stated by Giovanni Sartori, the terms of "left-wing" and "right-wing" are "open and empty vessels" which will be filled with various contents depending on the social and political circumstances. The omission of this rule in the CMP method calls into question the theoretical value of international comparative analyses. As shown by findings of different researchers, the ideological positions determined on the basis of the CMP method do not reflect the actual positions of parties in such countries as Austria, Belgium, Denmark, Germany, Greece, the Netherlands and Switzerland [Franzmann, Kaiser 2006: 164; Dinas, Gemenis 2010: 428; Hug, Schulz 2007: 305-330]. When studying the programs of Polish political parties, it was noted that some categories distinguished in the CMP method has marginal significance in the narration presented by the parties.

A different problem is that the categories taken into consideration when estimating the RILE index mainly demonstrate relations with economics, whereas other areas of concern are underrepresented (e.g. axiological issues), despite their rising significance as a catalyst of ideological differences between parties. As noted by Waldemar Wojtasik, the economic plane, fundamental for the left-right wing division since the industrial revolution, has lost the ability to polarise the entities in the political arena in modern times. When the western world entered the period of economic prosperity after World War II, the left-right wing scheme, thus far exploring the socio-economic differences (labour-capital, employers-employees), began to include the axiological plain, constituting an arena for the rising conflict of materialism-post-materialism [Wojtasik 2011: 54-55]. According to Oddbjørn Knutsen, "the left-right semantics, which was related to conflicts preceding the industrial revolution, remained strongly correlated with the dominant conflicts in the industrial era and is increasingly related to a new set of material and post-material values" [Knutsen 1995: 87]. The broadening of the dyad's semantic framework opened the door for recognising ideological identities not only on the socio-economic basis, but also through the lens of axiological and cultural identifiers. The left-wing, which is traditionally received as a social justice advocator, gained broader connotation, thanks to which it was becoming associated by the public opinion as a supporter of gender equality, environmental 
protection, multi-culturalism, human rights, tolerance. A similar thing happened to the right-wing which, by leaving the historically specified doctrinal stereotype, was becoming associated with the role of guardian of a traditional way of life, family and national interests. It seems that this type of revaluations should be reflected in the index used to estimate the parties' positions in the ideological axis.

\section{EXPERT SURVEY (EXS)}

The Expert Survey (ExS) method is currently often transferred to research applications, similarly to CMP. It often serves the purpose of assigning a party a position in the left-right wing continuum or of determining the parties' attitude towards selected issues (e.g. towards European integration) [Ray 1999: 283-306]. It is used for statistical studies encompassing a narrow time series (e.g. single election), but also for dynamic studies, the time series of which is substantially broader (even several elections). The practical potential of this method is also confirmed by the fact that it can be useful to the same degree regardless of whether the study encompasses a single party system [Laver 1998: 159-171] or an aggregate of party systems [Huber, Inglehart 1995: 73-111]. The broadening of the analysis' range to political formation groups derived from many countries makes the study designing team to face the need of selecting the experts demonstrating a detailed knowledge about the studied topic.

One of the more known studies with international range, based on the Expert Survey approach, is conducted by The Chapel Hill research group. The study features evaluation of the political parties' attitude towards European integration, positions the parties in the left-right wing axis and verifies the parties' attitude towards important political issues (e.g. migration). The first such study was conducted in 1999. It covered fourteen West European countries and 143 parties. The measurement's range was increased in subsequent editions. In 2014, the study covered 31 European countries (aside from EU member states, also Norway, Switzerland and Turkey). Expert evaluations were collected for a total of 268 political parties ${ }^{6}$.

In comparison to other methods used in political sciences, the ExS avoids the weaknesses characteristic for competitive research approaches. Insofar as accumulation of knowledge about the parties' ideological positions based on electoral group studies can bear great risk due to the generally low level of the society's political socialisation, the use of experts' knowledge provides greater guarantee of acquiring more reliable information [Mair 2001: 15]. The ExS method utilising expert knowledge allows for recording changes in the parties' ideological positions with greater frequency than the CMP method. The experts - due to their profession and scientific interests - constantly observe and analyse political party behaviours, thereby enabling them to grasp the changes to determine their intensity and direction. The applied

\footnotetext{
${ }^{6}$ https://www.chesdata.eu/our-surveys (access: 15.10.2019).
} 
time interval depends basically on the study's organisational and financial aspects, whereas the CMP method allows for tracking changes at the political parties' level in four- or five-year intervals (usually the time of an election cycle).

In political science literature, it is possible to find a view that the ExS method does not generate reliable data on the parties' positions and that the attempts at measuring the ideological changes phenomenon should be conducted using other methods [Gemenis, van Ham 2014: 33-47]. Ian Budge brought many restrictions on this method in the scientific discourse, nevertheless, he did not undermine the sense of using it in the context of studying political formations. He pointed to the issue of understatement of the party's aspect taken into consideration when experts determine its position in the ideological axis. In short, whether the observation concerns the behaviours of party leaders, lower-level activists or the party as a whole [Budge 2000: 105-106]. He also deemed problematic the way in which experts understand the abstract categories of "left-wing" and "right-wing". These categories do not have an arbitrary meaning, but develop substance mainly thanks to enveloping them into the given country's social and cultural context ${ }^{7}$. Many empirical materials have been collected to confirm the thesis that the understanding of the left-right wing dichotomy acquired a different meaning in Central and Eastern Europe, including Poland, than in the developed Western European countries [Grabowska, Szawiel 2003; Sitter 2002: 425-451]. This is due to the different historical experiences and the lack of development in Central and Eastern European countries of traditional socio-political divisions which shaped the cross-party rivalry models in the West. Budge also emphasised that when using the ExS method, it is basically impossible to know whether experts evaluate the intents, forecasts, declarations formulated by political environments, or the parties' actual activity [Budge 2000: 109-110]. The last doubt concerned the study's timeframe. It can be brought to the question: what time perspective is to be adopted by experts who evaluate the parties' ideological positions? Should their judgment be based on the most current observations or whether they should consider conclusions from a longer analysis (if the second option is acceptable, the other unknown is how far reaching should the expert's observation be).

On the other hand, Luigi Curini took a critical look at the ExS method. The ExS method's defect identified by him came down to the statement that experts' evaluations can be distorted by subjective views of the experts taking part in the study [Curini 2010: 300]. Experts that are unfriendly to, e.g. the far right demonstrate greater inclination to position right-wing parties more to the right than experts with an indifferent approach towards the right-wing.

7 The research team led by Ryan Bakker proved [Bakker et al. 2014: 1-8] that experts from different countries similarly understand the meaning of "left-wing" and "right-wing". This type of finding reinforces the quality of the empirical materials collected using the ExS method and speaks for using this method in international studies. 


\section{QUANTITATIVE ANALYSIS OF ELECTION PROGRAMS VERSUS EXPERT SURVEY. SIMILARITIES AND DIFFERENCES}

The compared approaches demonstrate a similarity in terms of transposing the leftright wing division into the field of scientific applications. They deem an antithetical dyad as a useful tool that descriptively systematises the parties' ideological identities. Both approaches adopt the position of Downs, according to which, "each party takes its stance in various issues and each stance can be assigned a position in the left-right wing scale" [Downs 1957b: 132]. As part of the described approaches, the dyad acts as a general communications medium used to comprehensibly describe the processes, trends and phenomena concerning political rivalry and party behaviours.

It is also important that the compared approaches apply the spatial modelling. Both the CMP and ExS position parties in (one- and two-dimensional) ideological spaces and based on the party's position determine, firstly, the ideological identity of the given party and, secondly, the ideological changes that occurred in the given environment since the last measurement.

Another common element for both approaches is that they provide data that can be used to make international comparisons. The comparisons can be made at the political actors' level. Then, it is determined whether the ideological transformations in the left-wing and right-wing environments demonstrate common features in an international scale. Both approaches are also helpful in comparing party systems in terms of such important parameters as the degree of ideological polarisation or the direction of cross-party rivalry.

A common denominator for both approaches is also the fact that they enable analysing the ideological change phenomenon within a time frame. The collection of data on the historical ideological positions of parties and their comparison with the current positions allows for discovering the path travelled in an ideological sense by particular political entities. This allows for the collection of knowledge about the parties' behaviours in a long time frame.

The key difference between the CMP and the ExS is the data source from which they derive information about the parties' ideological positions. For this purpose, the CMP explores election manifests, i.e. documents developed for the purposes of an election campaign, which are approved by the official party bodies, and around which an intra-party consensus is usually built. In the Expert Survey method, the monitoring of the parties' ideological evolution is done by using experts' knowledge. However, the problem is that it is basically impossible to know the basis on which the experts built their judgment on the parties' ideological positions. Did they rely on an election program analysis, or did they consider public statements of party leaders, or did they base their judgment on the manner in which the political parties present themselves in the media discourse? It is impossible to say whether the experts taking part in the Expert Survey build their judgment in a uniform manner (whether it is by taking into consideration the same aspects, or whether they focus on evaluating different issues). 
The inability of resolving this dilemmas causes the verification of the information collected from the experts during the study to be basically impossible, which reduces the research findings' reliability.

The issue that differentiates both approaches is the frequency with which the political parties' ideological changes can be measured. In the case of the CMP, the measurement frequency depends on the electoral cycle. Therefore, such a measurement is usually possible only one per four years (or per five years), provided that the parliamentary term is not shortened. The Expert Survey's flexibility makes the time intervals of tracking ideological changes in parties to be shaped freely, which undoubtedly must be deemed as an advantage of the ExS approach. However, on the other hand, it is necessary to emphasise that the CMP approach allows, without much difficulty, to reconstruct the parties' past ideological positions, whereas the ExS approach-based measurement would be burdened with a great risk of error.

Table 1. SWOT analysis of CMP and ExS

\begin{tabular}{|c|c|c|}
\hline $\begin{array}{l}\text { Evaluation } \\
\text { categories }\end{array}$ & Comparative Manifesto Project & Expert Survey \\
\hline Strengths & $\begin{array}{l}\text { - High reliability of data sources (officially } \\
\text { adopted election programs), constituting } \\
\text { the basis for the CMP's specification of } \\
\text { the parties' ideological positions } \\
\text { - Ability to reconstruct the parties' past } \\
\text { ideological positions }\end{array}$ & $\begin{array}{l}\text { - High flexibility enabling measurements at any } \\
\text { time intervals }\end{array}$ \\
\hline Weaknesses & $\begin{array}{l}\text { - Measurement frequency dependent on the } \\
\text { electoral cycle } \\
\text { - Overrepresentation of social and econo- } \\
\text { mic issues in estimating the RILE index, } \\
\text { which constitutes the basis for classifying } \\
\text { parties to ideological axis positions } \\
\text { - Use of a one-dimensional ideological } \\
\text { axis, which hinders specification of the } \\
\text { issues (social and economic or world } \\
\text { view) in which the given party changed } \\
\text { its stance }\end{array}$ & $\begin{array}{l}\text { - Limited ability of a retrospective classification } \\
\text { of parties to ideological positions } \\
\text { - Lack of ability to determine the basis (pro- } \\
\text { gram analysis, leader statements' evaluation } \\
\text { and other) for expert evaluations on the } \\
\text { parties' ideological positions } \\
\text { - Asymmetry in the experts' knowledge on } \\
\text { particular political parties } \\
\text { - Determining the parties' positions in the } \\
\text { ideological axis based on contradictory expert } \\
\text { evaluations }\end{array}$ \\
\hline Opportunities & $\begin{array}{l}\text { - Broad capabilities of international compa- } \\
\text { risons } \\
\text { - Collection of data enabling the de- } \\
\text { scription of key parameters for evaluating } \\
\text { the direction of growth of party systems }\end{array}$ & $\begin{array}{l}\text { - Broad capabilities of international compari- } \\
\text { sons } \\
\text { Collection of data enabling the description of } \\
\text { key parameters for evaluating the direction of } \\
\text { growth of party systems }\end{array}$ \\
\hline Risks & $\begin{array}{l}\text { - Obtaining distorted or erroneous results } \\
\text { of measuring the ideological positions of } \\
\text { particular parties due to acontextual cate- } \\
\text { gories, which is taken into consideration } \\
\text { when estimating the RILE index }\end{array}$ & $\begin{array}{l}\text { - Obtaining distorted or erroneous results } \\
\text { of measuring the ideological positions of } \\
\text { particular parties due to experts' insufficient } \\
\text { knowledge and differences in the reception of } \\
\text { categories used for party evaluation (especial- } \\
\text { ly in international research) }\end{array}$ \\
\hline
\end{tabular}

Source: Author's own study.

The differences in tracking the parties' ideological changes often imply discrepancies in their position in the ideological space. As demonstrated by Kenneth Benoit and 
Michael Laver's research, the CMP and ExS results are often contradictory when it comes to assigning parties to the left-wing or right-wing groups [Benoit, Laver 2007: 96-100]. On the other hand, the research of Michael D. McDonald, Silvia M. Mendes and Myunghee Kim shows that the CMP approach is more sensitive to recording the parties' transitions in the left-right wing axis, whereas the $\mathrm{ExS}$ a relatively flexible image of the political actors' behaviours [McDonald, Mendes, Kim 2007: 62-75].

\section{CONCLUSIONS}

This paper is devoted to the execution of two research objectives. On the one hand, it presents the static and dynamic ideological identity frameworks. It was demonstrated that the static framework basically does not live up to the contemporary conditions of cross-party rivalry. This causes the need to consider the dynamic perspective, which treats a party's ideological identity as a labile, contextual, open and constantly transforming creation. The consideration of the dynamic ideological identity framework makes political reality researchers face the methodological dilemma of which tools to use to track the political actors' ideological evolution. The other research purpose was to present five research approaches enabling the execution of research projects aimed at determining the direction and scale of the parties' ideological changes. The paper also features a detailed comparison of two leading research approaches - the quantitative analysis of election programs (acc. to the CMP standards) and the Expert Survey.

Based on the conducted studies, it was demonstrated that both approaches are not free of serious weaknesses which reduce the value of their research findings. The weaknesses of both approaches can lead to the generation, in the best case, of inaccurate and in the worst case, of erroneous findings on the parties' ideological positions.

In the case of the CMP, the main weakness is the rigid, arbitrarily specified categorisation key, which is used for evaluating the contents of the studied parties' election manifestos. In the case of European elections, where the focus of groups is more on a narrow range of political issues (most often related to the EU and the Community's challenges), the use of this key would not be as problematic as in the case of national elections, during which the cross-party rivalry in particular countries is topically dispersed.

On the other hand, in terms of the Expert Survey, its main weakness is the data source used to acquire knowledge on the parties' ideological positions. This does not solely concern the limited knowledge of the experts taking part in the ExS studies. The main problem is that it is not possible to determine the aspects constituting the focus of experts during the evaluation of the parties' attitude towards particular issues. In the Chapel Hill Expert Survey, an additional problem is that experts evaluate the parties' attitude not so much to particular issues (e.g. attitude towards tax progression), but to topical blocks (e.g. economy or democratic freedoms and rights). 
The classification of parties' ideological positions based on procedures giving rise to such serious methodological doubts requires a greatly reserved approach to the results of the ExS study.

Taking into consideration the weaknesses and strengths of both approaches, it is necessary to state that the CMP, as a method of collecting data about party behaviours in ideological terms, has a great advantage over the ExS. The essence of this advantage is that the CMP analysis focuses on separate, strictly specified aspects of a party's activity (election program), whereas the experts' study does not even specify this issue. The election program, as the party's activity product, specifies the most important assumptions adopted by the given political environment on various aspects of the social and political reality. Due to the fact that it is an official document adopted by the authorised party bodies, the program must be treated as an information source characterised by a high level of reliability. The above deliberations lead to the conclusion that the CMP can be treated as a method constituting - despite certain restrictions - the basis for research projects aimed at measuring ideological changes in parties. In the political sciences' research workshop, the Expert Survey should have the status of a method supporting the research process. Basing the research activities solely on this method would be burdened with many methodological problems.

\section{BIBLIOGRAPHY}

Antoszewski, A. 2005. Partie polityczne Europy Środkowej i Wschodniej, Wydawnictwo Uniwersytetu Wrocławskiego, Poznań-Wrocław.

Bakker, R., Edwards, E., Jolly, S., Polk, J., Rovny, J., Steenbergen, M. 2014. Anchoring the experts: Using vignettes to compare party ideology across countries, "Research and Politics", no. 3.

Benoit, K., Laver, M. 2007. Estimating party policy positions: Comparing expert surveys and hand-coded content analysis, "Electoral Studies", no. 26.

Von Beyme, K. 1985. Political Parties in Western Democracies, Palgrave Macmillan, Aldershot.

Budge, I. 2000. Expert judgements of party policy positions: Uses and limitations in political research, "European Journal of Political Research", no. 37.

Budge, I. 2013. The Standard Right-Left Scale, https://manifesto-project.wzb.eu/down/papers/budge_rightleft-scale.pdf (access:10.10.2019).

Budge, I., Klingemann, H.-D. 2001. Finally! Comparative over-time mapping of party policy movement, [in:] Mapping Policy Preferences: Estimates for Parties, Electors, and Governments 1945-1998, I. Budge, H.-D. Klingemann, A. Volkens, J. Bara, E. Tanenbaum (eds.), Oxford University Press, Oxford.

Bukowska, X., Cześnik, M. 2002. Analiza treści programów wyborczych polskich partii politycznych 1991-2001, [in:] System partyjny i zachowania wyborcze. Dekada polskich doświadczeń, R. Markowski (eds.), Instytut Studiów Politycznych PAN, Warszawa.

Carrubba, C.J., Gabel, M., Murrah, L., Clough, R., Montgomery, E., Schambach, R. 2006. Off the record: Unrecorded legislative votes, selection bias and roll-call vote analysis, "British Journal of Political Science", no. 36.

Curini, L. 2010. Experts' political preferences and their impact on ideological bias an unfolding analysis based on a Benoit-Laver Expert survey, "Party Politics", no. 16.

Dinas, E., Gemenis, K. 2010. Measuring parties' ideological positions with Manifesto data: A critical evaluation of the competing methods, "Party Politics", no. 16. 
Downs, A. 1957a. An economic theory of political action in a democracy, "Journal of Political Economy". Downs, A. 1957b. An Economic Theory of Democracy, Harper \& Row, Publishers, New York.

Franzmann, S., Kaiser, A. 2006. Locating political parties in policy space: A reanalysis of Party Manifesto Data, "Party Politics", no. 12.

Gagatek, G. 2007. Geneza i ewolucja frakcji Europejskiej Partii Ludowej (Chrześcijańskich Demokratów) w Parlamencie Europejskim, "Studia Polityczne", no. 20.

Gallagher, M., Laver, M., Mair, P. 2001. Representative Government in Modern Europe, Open University Press, Boston.

Gemenis, K., van Ham, C. 2014. Comparing methods for estimating parties' positions in voting advice applications, [in:] Matching Voters with Parties and Candidates: Voting Advice Applications in a Comparative Perspective, D. Garzia, S. Marschall (eds.), ECPR Press, Colchester.

Grabowska, M., Szawiel, T. 2003. Budowanie demokracji. Podziały spoleczne, partie polityczne i spoteczeństwo obywatelskie w postkomunistycznej Polsce, Wydawnictwo Naukowe PWN, Warszawa.

Hloušek, V., Kopeček, L., 2010. Origin, Ideology and Transformation of Political Parties: East-Central and Western Europe Compared, Routledge, Aldershot.

Huber, J.D., Inglehart, R. 1995. Expert interpretations of party space and party locations in 42 societies, "Party Politics", no. 1.

Hug, S., Schulz, T. 2007. Left-right positions of political parties in Switzerland, "Party Politics", no. 13.

Jahn, D. 2011. Conceptualizing Left and Right in comparative politics: Towards a deductive approach, "Party Politics", no. 17.

Klingemann, H.-D. 1987. Election programs in West Germany: 1949-1980, explorations in the nature of political controversy, [in:] Ideology, Strategy and Party Change: Spatial Analyses of Post-War Elections Programmes in 19 Democracies, I. Budge, D. Robertson, D. Hearl (eds.), Cambridge University Press, Cambridge.

Knutsen, O. 1995. Value orientations, political conflicts and left-right identification: A comparative study, "European Journal of Political Research", no. 28.

Laver, M. 1998. Party policy and cabinet portfolios in Ireland, 1997: Results from an expert survey, "Irish Political Studies", no. 13.

Maguire, M. 1983. Is there still persistence? electoral change in Western Europe, 1948-1979, [in:] The Western European Party System. Continuity and Change, H. Daalder, P. Mair (eds.), SAGE Publications, London.

Mair, P. 2001. Searching for the positions of political actors: A review of approaches and critical evaluation of expert surveys, [in:] Estimating the Policy Position of Political Actors, M. Laver (ed.), Routlege, London.

Mair, P., Mudde, C. 1998. The party family and its study, "Annual Review of Political Science", no. 1.

Markowski, R. 2002. Propozycja „Manifesto Research Group”: metoda, wyniki, problem - komentarz, [in:] System partyjny i zachowania wyborcze. Dekada polskich doświadczeń, R. Markowski (ed.), Instytut Studiów Politycznych PAN, Warszawa.

McDonald, M.D., Mendes, S.M., Budge, I. 2004. What are elections for? Conferring the median mandate, "British Journal of Political Science", no. 34.

McDonald, M.D., Mendes, S.M., Kim, M. 2007. Cross-temporal and cross-national comparisons of party left-right positions, "Electoral Studies", no. 26.

Mikhaylow, S., Laver, M., Benoit, K. 2012, Coder reliability and misclassification in the human coding of party manifestos, "Political Analysis", no. 20.

Mudde, C. 2002. The Ideology of the Extreme Right, Manchester University Press, Manchester-New York. Noël, A., Therién, J.-P. 2008. Left and Right in Global Politics, Cambridge University Press, Cambridge. Pelizzo, R. 2003. Party positions or party direction?, "West European Politics", no. 26.

Rafałowski, R. 2014. Fragmentacja i polaryzacja systemów partyjnych w krajach pokomunistycznych, http://www.depotuw.ceon.pl/bitstream/handle/item/711/Rafa\%C5\%82owski\%2Wojciech\%20-\%20 doktorat.pdf? sequence $=1$ (access: 2.10.2019). 
Ray, L. 1999. Measuring Party Orientations towards European Integration: Results from an Expert Survey, "European Journal of Political Research", no. 36.

Sitter, N. 2002. Cleavages, party strategy and party system change in Europe East and West, "Perspectives on European Politics and Society", no. 3.

Werner, A., Lacewell, O., Volkens, A. 2011. Manifesto Coding Instructions, https://manifesto-project.wzb. eu/down/papers/handbook_v4.pdf (access: 15.10.2019).

Wojtasik, W. 2011. Lewica i prawica w Polsce. Aspekty ekonomiczno-spoleczne, Oficyna Wydawnicza „Humanitas”, Sosnowiec.

Zuba, K. 2012. Polska scena polityczna: ciagłość i zmiana, Wydawnictwo Sejmowe, Warszawa.

\section{METODOLOGICZNE ASPEKTY BADANIA ZMIAN IDEOLOGICZNYCH W KONTEKŚCIE PARTII POLITYCZNYCH}

Abstrakt: Celem artykułu jest analiza aspektów metodologicznych związanych z badaniem zmian ideologicznych w partiach politycznych. W pracy porównano analizę ilościową programów wyborczych i ankiety eksperckiej, oceniono ich mocne i słabe strony oraz przeanalizowano możliwości ich zastosowania. Hipoteza przyjęta w artykule jest następująca: analiza ilościowa programów wyborczych jest obciążona mniejszymi słabościami metodologicznymi niż ankieta ekspercka, a zatem jest bardziej niezawodnym narzędziem do pomiaru zmian ideologicznych w środowisku partii politycznych.

Slowa kluczowe: partie polityczne, zmiany ideologiczne, analiza ilościowa programów wyborczych, ankieta ekspercka

\section{BIOGRAPHY}

Michal Niebylski, $\mathrm{PhD}$, researcher employed as an assistant professor at the Institute of Political Science and Administration at the University of Opole. E-mail: mniebylski@uni.opole.pl 